\title{
X-Ray Diffraction Studies of Rice Husk Ash-An Ecofriendly Concrete at Different Temperatures
}

\author{
Patnaikuni Chandan Kumar, Nutulapati V. S. Venugopal \\ Department of Civil Engineering \&Chemistry, GITAM University, Visakhapatnam, India \\ Email: Venu7000@gmail.com
}

Received Jaunary 20, 2013; revised February 20, 2013; accepted March 15, 2013

Copyright (C) 2013 Patnaikuni Chandan Kumar, Nutulapati V. S. Venugopal. This is an open access article distributed under the Creative Commons Attribution License, which permits unrestricted use, distribution, and reproduction in any medium, provided the original work is properly cited.

\begin{abstract}
In the majority of rice producing countries, much of the husk produced from the processing of rice is either burnt or dumped as waste. Rice husks are one of the largest readily available but most under-utilized biomass resources, being an ideal fuel for electricity generation. In this communication the author reported the $\mathrm{X}$-ray diffraction studies on rice husk ash (RHA) concrete samples heated at $300^{\circ} \mathrm{C}$ and $1000^{\circ} \mathrm{C}$ which were compared and observed that at $300^{\circ} \mathrm{C}$ the inner surface of the specimen shows an extra compound. Copper Iron Lead Telluride $\mathrm{Cu}_{3} \mathrm{FePbTe}_{4}$ along with $\mathrm{SiO}_{2}$, $\mathrm{Al}_{5} \mathrm{Fe}_{2} \mathrm{ZnO}_{4}$ was present on the surface which also and might be responsible for imparting additional strength to $7.5 \%$ RHA concrete at $300^{\circ} \mathrm{C}$. The X-ray diffraction studies of samples exposed to $1000^{\circ} \mathrm{C}$ on temperature showed that the additional chemical compounds formed at lower temperatures were not found at $1000^{\circ} \mathrm{C}$ at outer and inner surfaces of the sample indicating its possible reason for exhibiting poor strengths for all specimens. The outer surface of the $1000^{\circ} \mathrm{C}$ heated specimen showed a compound named dichloroglyoxime $\mathrm{C}_{2} \mathrm{H}_{2} \mathrm{Cl}_{2} \mathrm{~N}_{2} \mathrm{O}_{2}$ along with $\mathrm{SiO}_{2}$ but the inner surface of the same sample showed $\mathrm{SiO}_{2}$ alone.
\end{abstract}

Keywords: Rice Husk Ash Concrete; X-Ray Diffraction Studies; Different Temperature Environment

\section{Introduction}

Rice covers $1 \%$ of the earth's surface and is a primary source of food for billions of people. Globally, approximately 600 million tons of rice paddies are produced each year. The ash is $92 \%$ to $95 \%$ silica $\left(\mathrm{SiO}_{2}\right)$, highly porous and lightweight, with a very high external surface area. Its absorbent and insulating properties are useful to many industrial applications, and the ash has been the subject of many research studies. If a long term sustainable market and price for rice husk ash (RHA) can be established, then the viability of rice husk power or co-generation plants are substantially improved. Apart from the socioeconomic implications of durability, there is also a clear link between durability and the environment. By extending the life cycle of construction materials, we conserve valuable natural resources. The worry on the use of RHA concrete is not only limited to structural stability, but also to its durability in designing concrete structures.

Mauro M Tashima et al. [1] studied how different grades of RHA concrete can influence its physico-mechanical properties. Many researchers [2-5] explained the several key properties of high strength concrete using rice husk ashes (RHAs). RHAs were obtained from two sources: India and Vietnam were used with various contents to partially replace for cement binder in high strength concrete. Key properties of concrete, including slump, density, compressive strength, water and chloride permeability resistances, were investigated in compareson between samples without using RHA and samples using two types of RHAs. Muhammad Shoaib Ismail et al. [6] studied the effect of RHA as a $10 \%-30 \%$ replacement of cement. Moayad N. Al-Khalaf et al. [7] shown that Rice husk ash was prepared as a pozzolana by a special process such that the final product conformed to engineering requirements in terms of physical and chemical properties, and the silica remained in an amorphous form with a minor amount of unburnt carbon. Bui D., Hu J. et al. [8] reported that RHA has been used as a highly reactive pozzolanic material to improve the microstructure of the interfacial transition zone (ITZ) between the cement paste and the aggregate in high-performance concrete. Ahmadi M. A. et al. studied the development of mechanical properties up to 180 days of self compacting and ordinary concretes with rice-husk 
ash (RHA) two different replacement percentages of cement by RHA $10 \%$, and $20 \%$, and two different water/cementicious material ratios (0.40 and 0.35$)$ and it is concluded that 20\% RHA concrete provides a positive effect on the Mechanical properties at age after 60. All the earlier studies are on normal, fly ash and silica fume concretes. The studies on RHA concretes are very few. The studies of RHA concretes are mostly considering the percentage of replacements of $0,5,10,15,20$. Research studies on the above materials like Fly Ash, metakaoline etc. are abundant. However, research in the field of Rice Husk Ash concrete which is used as potential mineral admixture in concrete is scanty. Disposal of RHA coupled with environmental problem necessitated a study on RHA concretes. However, it was also found from the literature that earlier studies pertaining to the fire resistance of RHA concrete was very limited. Hence, in the present study the basic properties like strength, durability, fire resistance and other aspects of the RHA concretes were proposed for investigation. Therefore, in this communication the X-ray diffraction studies on RHA concrete samples heated at $300^{\circ} \mathrm{C}$ and $1000^{\circ} \mathrm{C}$ were compared.

\section{Experimental}

\subsection{Rice Husk Ash}

Rice Husk Ash used in the present experimental study was obtained from Orissa, India. General specifications, Physical Properties and Chemical Composition of this RHA used in this study which is furnished by the supplier are given in Tables 1, 2 and $\mathbf{3 .}$

Table 1. Specifications of rice husk ash.

\begin{tabular}{cc} 
Silica & $90 \%$ minimum \\
Humidity & $2 \%$ maximum \\
Mean Particle Size & 25 microns \\
Color & Grey \\
Loss on Ignition at $\mathbf{8 0 0}^{\circ} \mathbf{C}$ & $4 \%$ maximum \\
\hline
\end{tabular}

Table 2. Physical properties of rice husk.

\begin{tabular}{cc}
\hline Physical State & Solid-Non Hazardous \\
Appearance & Very fine powder \\
Particle Size & 25 microns-mean \\
Color & Grey \\
Odour & Odourless \\
Specific Gravity & 2.3 \\
\hline
\end{tabular}

Table 3. Chemical properties of rice husk ash.

\begin{tabular}{|c|c|}
\hline $\mathrm{SiO}_{2}$ & $93.80 \%$ \\
\hline $\mathrm{Al}_{2} \mathbf{O}_{3}$ & $0.74 \%$ \\
\hline $\mathrm{Fe}_{2} \mathrm{O}_{3}$ & $0.30 \%$ \\
\hline $\mathrm{TiO}_{2}$ & $0.10 \%$ \\
\hline $\mathrm{CaO}$ & $0.89 \%$ \\
\hline MgO & $0.32 \%$ \\
\hline $\mathrm{Na}_{2} \mathrm{O}$ & $0.28 \%$ \\
\hline $\mathbf{K}_{2} \mathbf{O}$ & $0.12 \%$ \\
\hline Loi & $3.37 \%$ \\
\hline
\end{tabular}

\subsection{Super Plasticizers}

Conplast SP430A2 which complies with IS: 9103 [9]. Type " $G$ " as a high range water reducing admixture for obtaining a workable mix was used.

\subsection{Preparation of Concrete Specimen}

All ingredients were placed in the mixer except water and mixed in the dry condition. Initially $80 \%$ of water is added and mixed for 75 seconds. The remaining quantity of water is then added to the concrete mix replaced with RHA in different percentages by weight of cement and mixed for 45 seconds. Super plasticizer dosages added to maintain the workability of $75 \mathrm{~mm}$ for all the mixes. Specimens were cast in $100 \times 100 \times 100 \mathrm{~mm}$ cube moulds. The specimens were compacted using table vibrator. For all specimens a constant compaction time of 50 seconds was adopted. All Samples were water cured for 28 days before carrying out all investigations. A total of 150 samples were cast and tested in the laboratory to study the sea water effect and rate of water absorption of RHA Concretes.

\subsection{Procedure}

Two samples each of $7.5 \%$ RHA replacement concrete specimens were collected in powder form. One from the outer and the other from the inner surface of the sample which was heated up to $300^{\circ} \mathrm{C}$ and $1000^{\circ} \mathrm{C}$ were tested for X-ray diffraction analysis.

\subsection{Instrument}

The analysis was carried with X-ray diffractometer (Model: 2036E201; Rigaku, Ultima IV, Japan).

\section{Result and Discussion}

Two samples each of $7.5 \%$ RHA replacement concrete 
specimens were collected in powder form. Below $300^{\circ} \mathrm{C}$ temperature and above $1000^{\circ} \mathrm{C}$ no significant compound was noticed. Above $1000^{\circ} \mathrm{C}$ one from the outer and the other from the inner surface of the sample which was heated up to $300^{\circ} \mathrm{C}$ and $1000^{\circ} \mathrm{C}$ were tested for X-ray diffraction analysis.

Outer surface of $300^{\circ} \mathrm{C}$ heated sample contains $\mathrm{SiO}_{2}$, Quartz and Nitro phenyl Benzamide $\left(\mathrm{C}_{13} \mathrm{H}_{10} \mathrm{~N}_{2} \mathrm{O}_{3}\right)$, compounds while inside surface of the sample contains Quartz, $\mathrm{SiO}_{2}, \mathrm{Al}_{3} \mathrm{Fe}_{2} \mathrm{ZNO}_{4}$ and Copper Iron Lead Telluride $\left.\left(\mathrm{Cu}_{3} \mathrm{Fe} \mathrm{Pb} \mathrm{Te}\right)_{4}\right)$ compounds which may be responsible for showing better strength. At $1000^{\circ} \mathrm{C}$ outer surface of the same specimen shows Quartz $\left(\mathrm{SiO}_{2}\right)$ and Dichloroglyoxime $\left(\mathrm{C}_{2} \mathrm{H}_{2} \mathrm{Cl}_{2} \mathrm{~N}_{2} \mathrm{O}_{2}\right)$ but inner layer shows only Quartz, $\mathrm{SiO}_{2}$ compounds. At $300^{\circ} \mathrm{C}$ and $1000^{\circ} \mathrm{C}$ temperatures for $7.5 \%$ RHA Concrete, variation was observed in formation of complex chemical compounds in different layers of the specimen. Hence strength variation at different temperatures was noted for different replacements of RHA Concrete specimens. The scientific reason is the moisture content present in the voids of concrete matrix starts evaporating after $100^{\circ} \mathrm{C}$ thereby making the concrete porous and weak responsible for strength with increase in temperatures. Further C-S-H gel is primarily responsible for the strength gain in concrete.
Since all the grades of concrete and all RHA replacements have been exposed to a range of temperatures from 300 degrees centigrade to 1000 degree centigrade, concrete looses the bond between the particles (C-S-H) in it and becomes weak and brittle resulting in lower strengths at higher temperatures. The XRD analysis of outer surface of 7.5\% RHA concrete heated at different temperatures were given in Figures 1-4.

\section{Conclusion}

X-ray diffraction studies on rice husk ash (RHA) concrete samples heated at $300^{\circ} \mathrm{C}$ and $1000^{\circ} \mathrm{C}$ were compared and observed that at $300^{\circ} \mathrm{C}$ the inner surface of the specimen shows an extra compound, Copper Iron Lead Telluride $\mathrm{Cu}_{3} \mathrm{FePbTe}_{4}$ along with $\mathrm{SiO}_{2}, \mathrm{Al}_{5} \mathrm{Fe}_{2} \mathrm{ZnO}_{4}$ which was present on the surface also and might be responsible for imparting additional strength to 7.5\% RHA concrete at $300^{\circ} \mathrm{C}$. The X-ray diffraction studies of samples exposed to $1000^{\circ} \mathrm{C}$ temperature showed that the additional chemical compounds formed at lower temperatures were not found at $1000^{\circ} \mathrm{C}$ on outer and inner surfaces of the sample indicating its possible reason for exhibiting poor strengths for all specimens. The outer surface of the $1000^{\circ} \mathrm{C}$ heated specimen showed a compound named

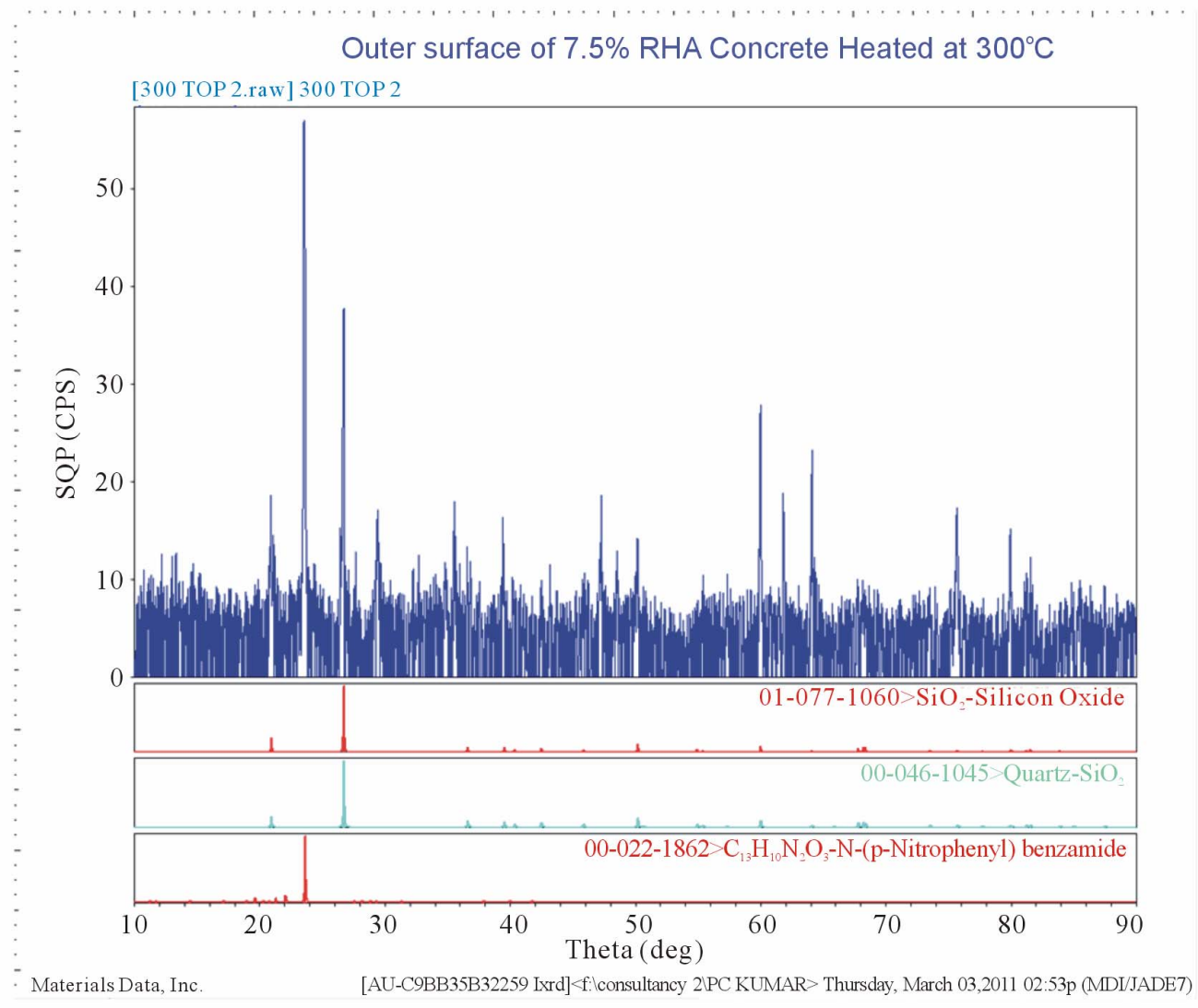

Figure 1. Cube 1: XRD analysis of outer surface of 7.5\% RHA Concrete heated at $300^{\circ} \mathrm{C}$. 


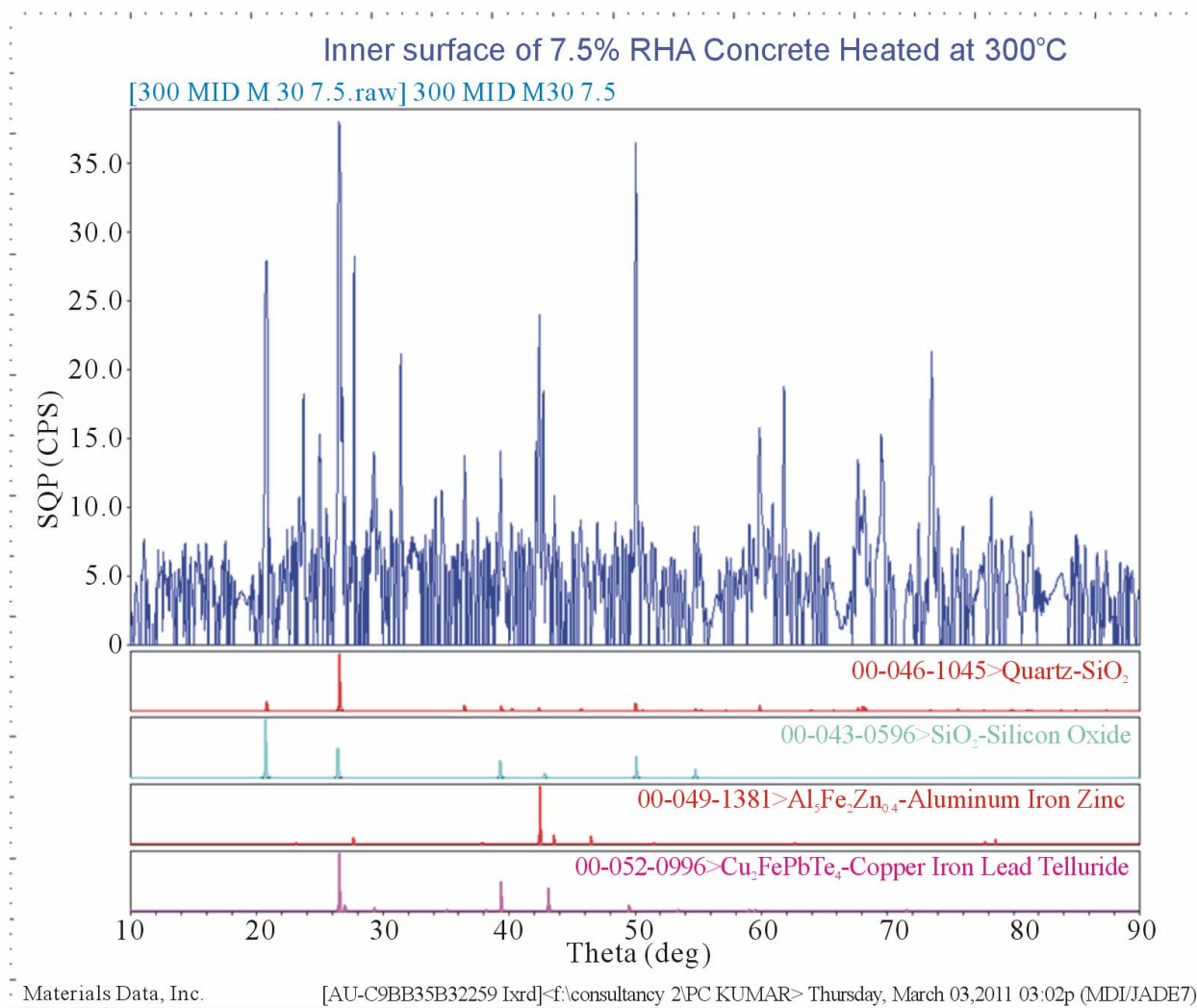

Figure 2. Cube 2: XRD analysis of Inner surface of 7.5\% RHA Concrete heated at $300^{\circ} \mathrm{C}$.

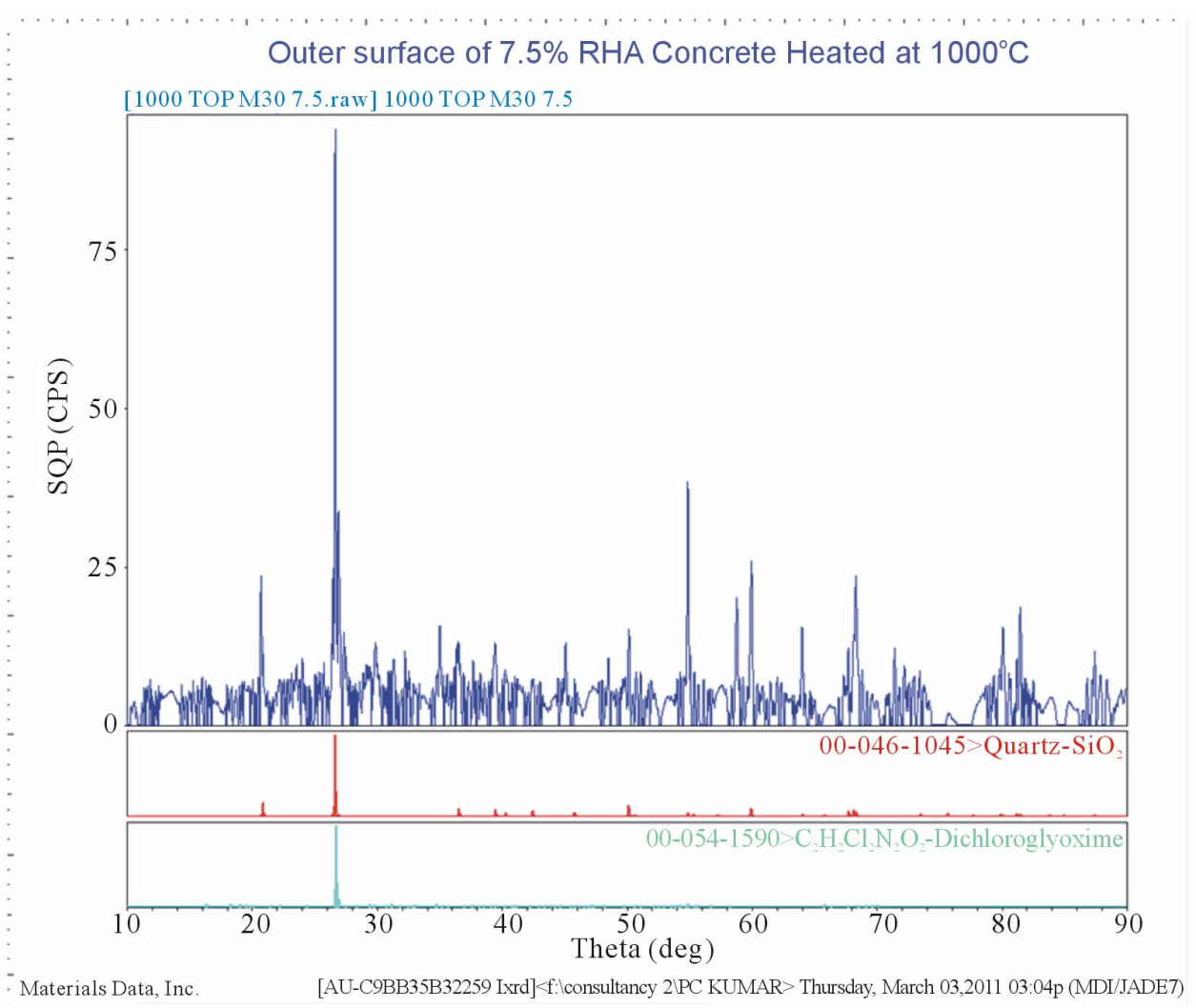

Figure 3. Cube 3: XRD analysis of Outer surface of $7.5 \%$ RHA Concrete heated at $1000^{\circ} \mathrm{C}$. 


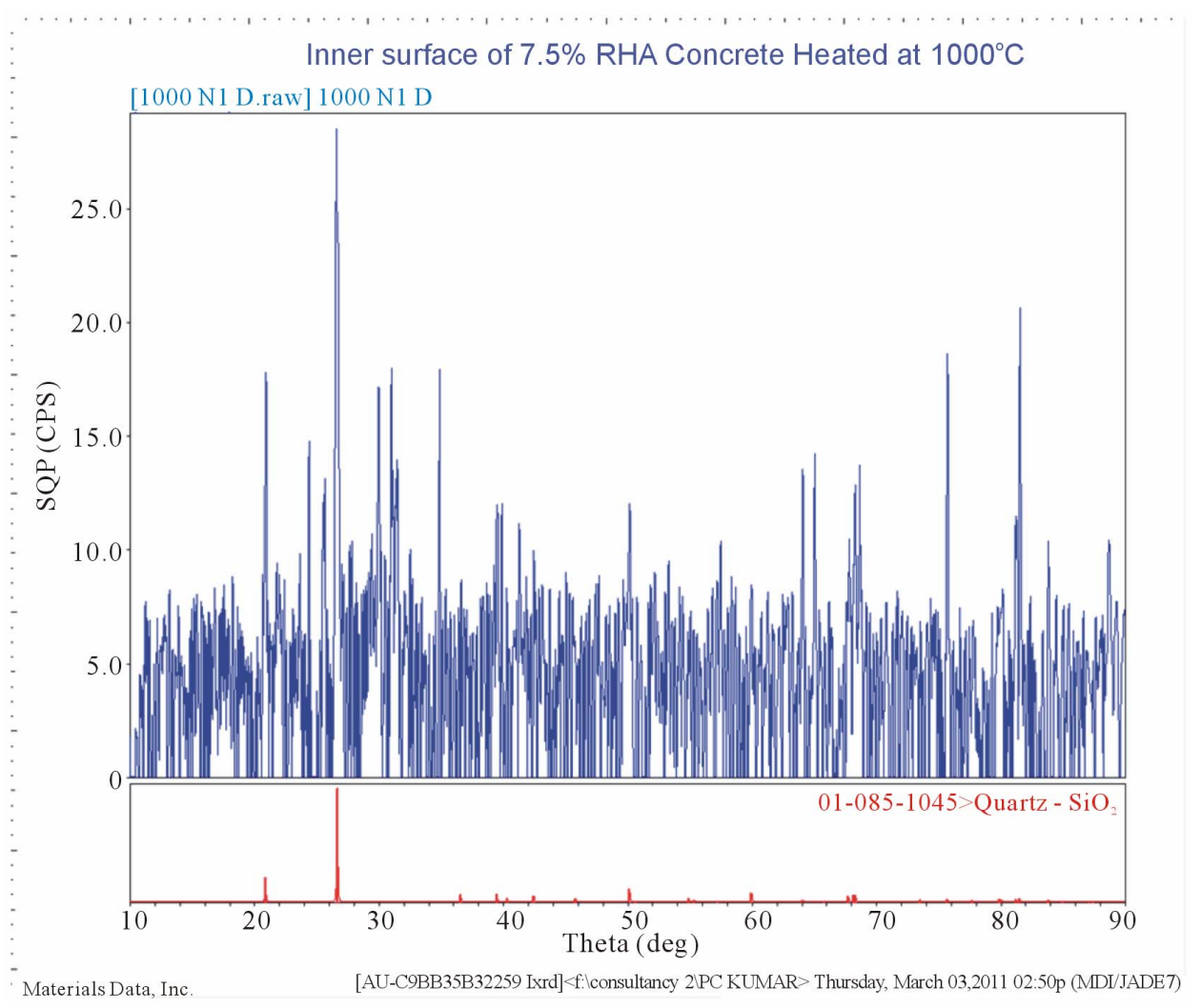

Figure 4. Cube 4: XRD analysis of Inner surface of $7.5 \%$ RHA Concrete heated at $1000^{\circ} \mathrm{C}$.

dichloroglyoxime $\mathrm{C}_{2} \mathrm{H}_{2} \mathrm{Cl}_{2} \mathrm{~N}_{2} \mathrm{O}_{2}$ along with $\mathrm{SiO}_{2}$.

\section{REFERENCES}

[1] M. M. Tashima, C. A. R. Silva, J. L. Akasaki and M. B. Barbosa, "Influence of Rice Husk Ash in Mechanical Characteristics of Concrete,” Supplementary Cementing Materials, 1985, pp. 780-790.

[2] D. Van Dong, P. D. Huu and N. N. Lan, "Effect of Rice Husk Ash on Properties of High Strength Concrete," The 3rd ACF International Conference-ACF/VCA, Vietnam, 11-13 November 2008, pp. 442-449.

[3] A. N. Givi, et al. "Contribution of Rice Husk Ash to the Properties of Mortar and Concrete: A Review,” Journal of American Science, Vol. 6, No. 3, 2010, pp. 157-165.

[4] M. H. Zhang, R. Lastra and V. M. Malhotra, "Rice-Husk Ash Paste and Concrete: Some Aspects of Hydration and the Microstructure of the Interfacial Zone between the Aggregate and Paste," Cement and Concrete Research, Vol. 26, No. 6, 1996, pp. 963-977. doi:10.1016/0008-8846(96)00061-0

[5] R. Jauvertgue, F. Rendell, S. Tamba and I. K. Cisse, "Properties of Cement-Rice Husk Mixture," Construction and Building Materials, Vol. 17, 2003, pp. 239-243.

[6] M. S. Ismail and A. M. Waliuddin, "Effect of Rice Husk Ash on high strength concrete," Construction and Building Materials, Vol. 10, No. 7, 1996, pp. 521-526. doi:10.1016/0950-0618(96)00010-4

[7] M. N. Al-Khalaf and H. A.Yousift, "Use of Rice Husk Ash in Concrete," The International Journal of Cement Composites and Lightweight Concrete, Vol. 6, No. 4. 1984, pp. 241-248. doi:10.1016/0262-5075(84)90019-8

[8] D. D. Bui, J. Hu and P. Stroeven, "Particle Size Effect on the Strength of Rice Husk Ash Blended Gap-Graded Portland Cement Concrete," Cement \& Concrete Composites, Vol. 27, No. 3, 2005, pp. 357-366. doi:10.1016/j.cemconcomp.2004.05.002

[9] IS: 9103, BS: 5075 and ASTM-C-494, Bereau of Indian Standards, New Delhi. 